\title{
Paleoecology of Late Eocene-Oligocene foraminiferal assemblages in a two-well transect across the North-East Newfoundland shelf
}

\author{
F.C. THOMAS, \\ Atlantic Geoscience Centre, P.O. Box 1006, Dartmouth, Nova Scotia, B2Y 4A2, Canada
}

\begin{abstract}
Core samples from the Paleogene of the Bonavista C-99 well on the northeast Newfoundland shelf and cuttings from downdip Blue H-28 contain foraminiferal assemblages which enable reconstruction of paleoenvironments along a downslope transect in Eocene through Late Oligocene-Miocene time. Comparison with coeval assemblages in North Sea wells with respect to structure and grain size of agglutinated taxa between the two areas reveal inter-basin differences.

Reconstruction of the paleobathymetry derived from foraminiferal analysis, confirms seismic evidence for shallowing at the Bonavista site beginning in the Early Oligocene. The relationship of the Bonavista assemblages to contour currents is explored with reference to modern regional analogues. Species such as Reticulophragmium amplectens, Haplophragmoides walteri, Eponides umbonatus and Uvigerina ex. gr. miozea-nuttalli persist stratigraphically higher in the deeper Blue site.

The paleoslope of this two-well transect is determined as approximately $0.48^{\circ}$ during the Middle to Late Eocene and $0.68^{\circ}$ during the Late Oligocene-Early Miocene. The bottom water hydrography of the transect can be evaluated by reference to these assemblages and a comparison to flysch-type agglutinated assemblages from a transect in the North Sea. The presence of an Upper Eocene-Middle Miocene hiatus at the Blue site contrasting with apparently continuous Tertiary deposition at Bonavista places a theoretical upper limit of $500-1000 \mathrm{~m}$ on the depth of the early Cenozoic western boundary undercurrent.
\end{abstract}

\section{INTRODUCTION}

The purpose of this study is to examine Paleogene benthic foraminiferal assemblages from a two-well transect on the Canadian Atlantic Margin in order to compare up- and downslope coeval faunas, and in turn to compare these to Paleogene assemblages from a well transect in the North Sea.

BP Columbia Bonavista C-99 is a new-field wildcat well situated approximately $175 \mathrm{~km}$ NNE of St. John's, Newfoundland, on Canada's east coast.

Originally drilled in 1974 , it was re-entered in 1975 and drilled to a total depth of $3778.9 \mathrm{~m}$. Texaco Shell et al. Blue H28, also a new-field wildcat, was drilled in 1979 at a site approximately $125 \mathrm{~km} \mathrm{NE}$ and depositionally downdip from Bonavista C-99. Both wells lie along multichannel seismic line 84-3 Lithoprobe East (Fig.1). Technical data on both wells are listed in Table 1.

Foraminiferal faunas from ditch cuttings in these wells have been the subject of several investigations (Gradstein, 1975; Gradstein \& Agterberg, 1982, among others); but Bonavista C-99 is unusual among Canadian offshore wells in that 3 conventional cores were drilled in Paleogene levels, at 1776.0 to 1782.8 , 2592.0 to 2600.9 and 3257.2 to $3266.2 \mathrm{~m}$. Since all regional Tertiary micropaleontological zonations for the Newfoundland Shelf have so far been based largely on ditch cuttings, the Bonavista cores provide a unique and important opportunity to examine in situ foraminiferal assemblages. Furthermore, their relatively undisturbed nature allows more detailed comparisons with synchronous material from other localities, such as the Blue H-28 well and localities in the North Sea (Jones, 1988). Also, foraminiferal faunas in core material may be examined in relation

\begin{tabular}{|c|c|c|}
\hline \multirow[t]{3}{*}{ Location } & Bonavista C-99 & Blue H-28 \\
\hline & $4908^{\prime} 05.98^{\prime \prime} \mathrm{N}$ & $4937^{\prime} 26.53^{\prime \prime} \mathrm{N}$ \\
\hline & $5114^{\prime} 24.47^{\prime \prime} \mathrm{W}$ & $4918^{\prime} 00.36^{\prime \prime} \mathrm{W}$ \\
\hline Rotary Table & $13.0 \mathrm{~m}$ & $15.0 \mathrm{~m}$ \\
\hline Water Depth & $329.2 \mathrm{~m}$ & $1486.0 \mathrm{~m}$ \\
\hline Totol Depth & $3778.9 \mathrm{~m}$ & $6103.0 \mathrm{~m}$ \\
\hline Cosing Points & $\begin{array}{l}762 \mathrm{~mm} @ 408.7 \mathrm{~m} \\
508 \mathrm{~mm} @ 691.3 \mathrm{~m} \\
340 \mathrm{~mm} @ 1217.1 \\
244 \mathrm{~mm} @ 2488.4 \mathrm{~m} \\
178 \mathrm{~mm} @ 3656.1\end{array}$ & $\begin{array}{l}762 \mathrm{~mm} @ 1605.4 \mathrm{~m} \\
508 \mathrm{~mm} @ 2055.9 \mathrm{~m} \\
340 \mathrm{~mm} @ 2975.0 \mathrm{~m} \\
244.5 \mathrm{~mm} @ 4420.2 \mathrm{~m}\end{array}$ \\
\hline $\begin{array}{l}\text { Sampling interval } \\
\text { (cultings) }\end{array}$ & $\begin{array}{l}9.1 \mathrm{~m} \text { somples } \\
18.3 \mathrm{~m} \text { intervals }\end{array}$ & $\begin{array}{l}10 \mathrm{~m} \text { samples } \\
20 \mathrm{~m} \text { intervais }\end{array}$ \\
\hline Conventional core \#1 & $\begin{array}{l}1776.0 \mathrm{~m}-1782.8 \mathrm{~m} \\
\text { (Rec. } 6.7 \mathrm{~m})\end{array}$ & none \\
\hline Conventional Core \#2 & $\begin{array}{l}22592.0 \mathrm{~m}-2600.9 \mathrm{~m} \\
\text { (Rec. } 8.2 \mathrm{~m} \text { ) }\end{array}$ & \\
\hline Conventional Core \#3 & $\begin{array}{l}33257.2 \mathrm{~m}-3266.2 \mathrm{~m} \\
(\operatorname{Rec} .8 .9 \mathrm{~m})\end{array}$ & \\
\hline Conventional Core \#4 & $\begin{array}{l}43769.2 \mathrm{~m}-3778.9 \mathrm{~m} \\
(\operatorname{Rec} .0 .8 \mathrm{~m})\end{array}$ & \\
\hline
\end{tabular}

Table 1. Technical data on PB Columbia Bonavista C-99 and Texaco Shell et al. Blue $\mathrm{H}-28$. 


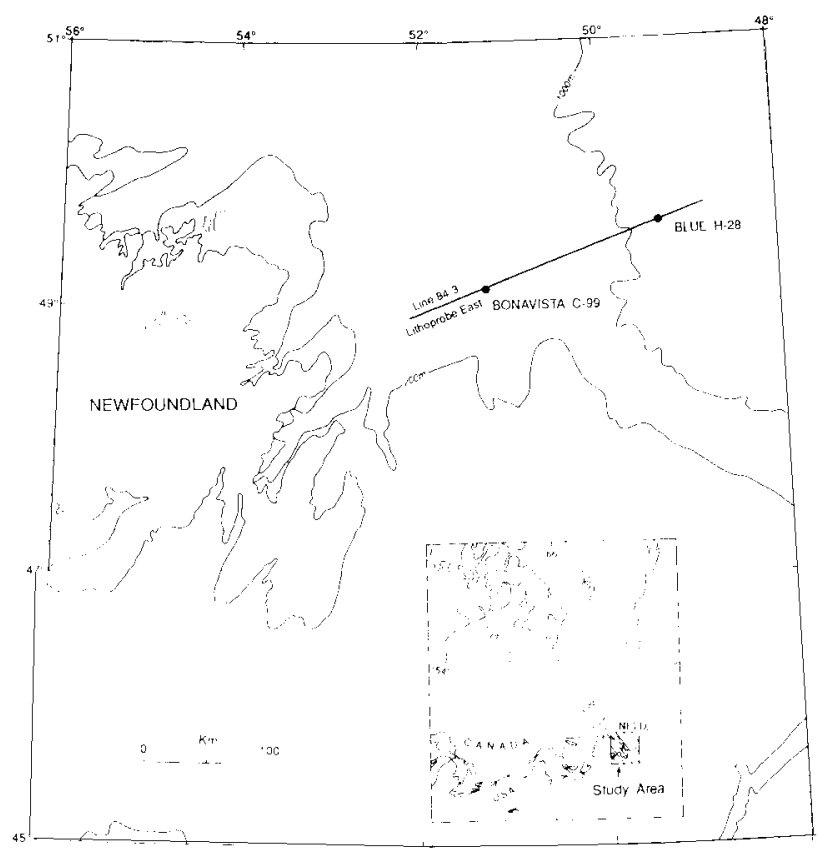

Fig 1 Location map of Bonavista C-99 and Blue H-28.

to more detailed litholoy analysis than is possible with ditch cuttings.

The Paleogene forammiferal suites observed in the Bonavista cores exhibit relatively little intra-sample variation in the fossil suites seen in each core, but marked differences in the foraminiferal content between cores.

These differences include calcareous vs. agglutinated ratios, absolute abundances and numbers of planktonic taxa present.

Deep-water agglutinated assemblages have been intensively studied in recent years (e.g. Miller et al., 1982; Schroder, 1986; Jones, 1988, ) and demonstrated to be useful for paleoecology and biostratigraphy. In particular, agglutinated assemblages similar to those found in Bonavista C-99 have been termed "flysch-type" by Gradstcin \& Berggren (1981) owing to their resemblance to classical agglutinated faunas first described from the Carpathian Flysch (Grzybowski, 1898).

This study examines the Bonavista C-99 assemblages recovered from the core material with reference to the recent literature in an attempt to place them in a paleoecological framework. Also, a comparison of the Bonavista foraminiferal samples is made with coeval downslope assemblages recovered from cuttings from the Blue $\mathrm{H}-28$ well, yielding clues to palcoenvironmental relationships of coeval downslope faunas.

\section{METHODS}

The three cored intervals from the Bonavista C-99 well were lithologically described in detail and 12 samples measuring roughly $100 \mathrm{~g}$ each were taken, usually from less silty beds at irregular intervals. Samples were disaggregated and washed through a 63-m sieve using the "Industrial Soap" method described by Thomas \& Murney (1985). This process yielded residues ranging from $10-75 \mathrm{~g}$. Samples were then oven dried and examined and splits were made to facilitate the counting procedure. Each split was then sieved using a 125 -micron screen to remove most of the silt, and counts of foraminifera were made on the $>125$-micron fraction.

20 ditch cuttings samples were examined from the interval $3830-4440 \mathrm{~m}$ of Blue $\mathrm{H}-28$. The samples were prepared in much the same manner as the Bonavista core material. The cuttings samples, however, are composite, representing $10 \mathrm{~m}$ intervals separated by $20 \mathrm{~m}$ gaps.

Exact counts of species abundances were not made on the Blue material because of the unquantitative nature of cuttings. Despite this, generalized relative abundances of species and planktonic:benthic ratios should be accurate for gross comparisons with the Bonavista core material. All Bonavista and Blue samples used in this survey are listed in Table 2 .

Biostratigraphic ages were determined by comparison, where possible, of the planktonic foraminiferal content with regional standard planktonic zonations such as that proposed by Gradstein and Srivastava (1980). Also employed was the quantitativelyderived (probabilistic) benthonic interval zonation erected by Gradstein and Kaminski (in prep.); benthic species were identified by comparison with the reference collections of these authors.

Picked slides containing the agglutinated components of five of the six samples used in Jones's (1988) North Sea transect study were also examined, along with count sheets for all six slides. For further information on this material, the reader is referred to Jones (1988).

The paleoslopes reconstructed and discussed below were derived by the use of a scale drawing. Chronostratigraphic columns representing the two wells were drawn, with key horizons such as the tops of series and unconformitics shown. The two columns were drawn exactly $12.5 \mathrm{~cm}$ apart. Since the two wells are actually $125 \mathrm{~km}$ apart, the horizontal scale is $1: 1,000,000$. The vertical scale used $(1 \mathrm{~cm}=200 \mathrm{~m})$ was 1 : 20,000 , resulting in a vertical exaggeration of $50 \mathrm{x}$. Lines were drawn between the two wells connecting corresponding points such as present water depth or the tops of the Middle Eocene, and the dips of these lines were measured with a protractor. These apparent angles were then divided by a factor of 50 to represent the vertical exaggeration. The resulting values then represent an approximation of the paleoslopes, uncorrected for compaction. Since burial depth below the seafloor for both wells is comparable, as are gross lithologies, correction for compaction is not necessary.

\section{RESULTS}

\section{Core descriptions - Bonavista C-99}

Core $1-\mathbf{1 7 7 6 . 0 - 1 7 8 2 . 8} \mathrm{m}$. The topmost two metres is composed of hard brown finely laminated silty limestone containing a few concretions of hard gray limestone with fine calcitic veins, and a few small vugs. The rest of the core consists of soft, friable brown silty calcareous mudstone, with occasional small lumps of gray limestone.

Core 2 - 2592.0-2600.9 $\mathrm{m}$. This core is composed almost entirely of finely interbedded light brown fine sandy siltstone and dark gray muddy siltstone. A few individual layers are up to a few centimetres thick, but most are much thinner. 


$\begin{array}{ccc} & \begin{array}{c}\text { Bonavisto (-99 } \\ \text { (conventional core) } \\ \mathrm{m}\end{array} & \begin{array}{c}\text { Blue H-28 } \\ \text { (cuttings) } \\ \mathrm{m}\end{array} \\ \text { Core 1 } & 1779.7 & 3830-3840 \\ & 1780.6 & 3860-3870 \\ \text { Core 2 } & & 3890-3900 \\ & & \\ & 2592.2 & 3920-3930 \\ & 2594.8 & 3950-3960 \\ & 2595.4 & 3980-3990 \\ & 2597.5 & 4010-4020 \\ & 2599.2 & 4040-4050 \\ & 2600.0 & 4070-4080 \\ & & 4100-4110 \\ \text { Core 3 } & & \\ & 3257.7 & 4130-4140 \\ & 3259.8 & 4160-4170 \\ & 3260.8 & 4190-4200 \\ & 3265.2 & 4220-4230 \\ & & 4250-4260 \\ & & 4280-4290 \\ & & 4310-4320 \\ & 4340-4350 \\ & 4370-4380 \\ & 4400-4410\end{array}$

Table 2. List of samples from Bonavista C-99 and Blue H-28

Core 3 - 3257.2-3266.2 m. This core consists entirely of uniformly dark gray indurated silty shale with fine laminations. According to the well history report (BP Exploration Canada, 1975) there is some dispersed dolomite present.

\section{Cuttings descriptions - Blue $\mathbf{H}-28$}

The lithology of samples from the Paleogene of Blue $\mathrm{H}-28$ were uniformly silty claystone, grading to silty shale in lower levels (Texaco Canada Resources Ltd., 1980).

\section{Foraminiferal assemblages - Bonavista C-99}

A total of 59 benthic and planktonic taxa including biogenic artifacts such as pyritized tubes and spheres were observed in the three cores.

Core 1 - The foraminiferal assemblage in the two samples from this core consists largely of agglutinated taxa, dominated by the tubular form Rhabdammina discreta. Other agglutinants include Ammodiscus latus, Haplophragmoides kirki and Cyclammina spp. Most of the agglutinated forms seen in this core are of medium to large size, often fairly coarse grained, and are white in colour. Calcareous forms such as Quinqueloculina robusta, Cibicidoides cf. C. eocaenus, Buliminella elegantissima, Lenticulina spp. and Nodosaria spp. are present in small numbers. Pyritized tubes, presumably representing small, infilled burrows, were roughly as common as $R$. discreta. There are no identifiable planktonic foraminifera. The samples are assigned to the Uvigerina ex gr. miozea-nuttali Zone (LateOligocene-Early Miocene) on the basis of comparison to cuttings samples from the same interval previously studied by Gradstein, (1975) and Gradstein \& Agterberg (1982).
Core 2 - The six samples from this core contain a mixed assemblage of numerous calcareous and agglutinated benthics and some planktonics. Common agglutinated species are Rhizammina sp., Rhabdammina discreta gr. and Ammosphaeroidina sp. Present in smaller numbers are Ammodiscus latus, Reophax sp., Haplophragmoides excavatum, Recurvoides sp. and Cyclammina cancellata, among others. Most specimens of these taxa are medium to coarse-grained, small and medium in size, and brown in colour. A diverse calcareous benthic component includes several Nodosaria and Dentalina forms such as Nodosaria cf. $N$. elegantissima and Dentalina cf. D. jacksonensis. Also present in small numbers are Turrilina robertsi, Bulimina midwayensis, Brizalina sp., Globocassidulina globosa, Nonion affine, Pullenia eocaenica and Gyroidina octocamerata, and very small numbers of several other species.

Planktonic foraminifera are fairly common, and include Turborotalia pomeroli, Globigerina aff. G. tripartita, $G$. aff. $G$. eocaenica and $G$. venezuelana, a suite indicating a position in the Turborotalia pomeroli interval Zone (Late Eocene; Gradstein \& Kaminski, in prep.).

Pyritized tubes or pyrite in any form, is not seen in these samples. Most samples, however, contain common small sphaerical to ovoid calcareous balls of light orange colour (as are most calcareous foraminifera). Their exact origin is undetermined, but they appear to be of biogenic provenance (possibly calcispherules).

Core 3 - The four samples from this core yield a predominantly agglutinated assemblage, dominated by Rhizammina spp., Haplophragmoides sp. and Saccamina sp. These species are fine to medium in texture, mostly small with some medium in size, and brown in colour. Present in smaller numbers are Glomospira charoides gr., Ammobaculites sp., Karreriella aff. K. pokornyi, Budashevella trinitensis and Reticulophragmium amplectens. Calcareous taxa are limited to a few Nodosariids and Lagenids, and no planktonics were identified. Pyritized tubes (as in Core 1) are the most abundant "taxon" in the core. Two samples also contain small pyritized spherical objects of unknown derivation. The presence of $R$, amplectens places this core in Gradstein \& Kaminski (in prep.) interval zones of Plectofrondicularia aff. paucicostata - Reticulophragmium amplectens.

\section{Foraminiferal assemblages - Blue $\mathbf{H - 2 8}$}

These samples all contain a predominantly agglutinated foraminiferal assemblage which changes in appearance from 3830 $\mathrm{m}$ down to $4440 \mathrm{~m}$. At $3830 \mathrm{~m}$ they tend to be relatively large, fairly coarse-grained in texture and nearly white in colour. Below this they change to darker, brownish colours, and generally become smaller, with much finer grain sizes, although some larger specimens persist in some intervals. Although this change is generally somewhat gradual, at about $4100 \mathrm{~m}$ there appears to be a slightly greater degree of change than in other levels.

Well-preserved planktonics represent usually less than $10 \%$ of the total specimens. Large Bathysiphon sp. and Cyclammina spp. are the most common agglutinated forms, together accounting for more than $30 \%$ of most samples. Various calcareous taxa are present in small numbers, with nodosariids easily dominant, especially Dentalina cf. D. jacksonensis. Pyritized tubes are virtually absent, although occasional fragments of pyritized microfossils such as small gastropods are present. 
As stated earlier, no exact counts of species abundances were made on the Blue cuttings material, but generalized relative abundances of species and planktonic:benthonic ratios should be accurate enough for gross comparisons with the Bonavista core material. The presence of Globoquadrina venezuelana, Globigerina linaperta, $G$. aff. eocaena, $G$. aff. angustium bilicata and Catapsydrax cf. dissimilis place the Blue samples in the Late Eocene Turborotalia pomeroli Zone $(3830-4340 \mathrm{~m})$ and the Middle Eocene Plectofrondicularia aff. paucicostata Reticulophragmium amplectens Zones (4340-4440 m).

\section{PALEOENVIRONMENTAL INTERPRETATION}

\section{Paleobathymetry}

The vertical succession of foraminiferal assemblages seen in the Bonavista cores and Blue cuttings reflect changing environmental conditions at the well sites through the Paleogene.

Bonavista C-99 Cores 3 and 2, representing earlier and later periods within the Late Eocene, are generally consistent in overall benthic content with faunas from a middle to upper bathyal environment, i.e. $200-1000 \mathrm{~m}$ water depth. Shallow water forms such as miliolids and lenticulinids are relatively rare, yet the large concentrations of planktonic forms characteristic of deep bathyal and abyssal conditions (Grunig \& Herb, 1980) are missing. Interestingly, one of the numerically more common calcareous benthics in Core 2 is Brizalina sp. In a study of the Paleogene of the Mackenzie Delta and Beaufort Sea, McNeil (1983) describes the presence of this or a similar Brizalina in an intermediate biofacies between "nearshore" and "deeper-water" environments, all of which were otherwise devoid of calcareous foraminifera. The lack of planktonic species and paucity of calcareous benthonics in Core 3 may well be a result of either disaerobic bottom conditions or diagenesis; in view of the abundance of pyritized tubes and "balls" in the samples.

\section{Bottom water hydrography}

The primarily agglutinated foraminiferal facies seen in Cores 1 and 3 of Bonavista and throughout the Upper Eocene section of Blue can be viewed as "flysch-type" sensu Gradstein \& Berggren (1981). More particularly, these would correspond to their "A" type fauna for Paleogene faunas containing fairly large, coarsetextured forms often dominated by tubular species or fragments. According to the model developed by these authors and supported by Miller et al. (1982), Toxwenius (1983) and Jones (1988) among others, flysch-type faunas developed in areas of deep water where organic-rich clastic sedimentation rates are high and bottom-water circulation is poor. These conditions can lead to a lowering of $\mathrm{pH}$ and $\mathrm{eH}$ values at the sediment-water interface, along with low oxygen and high carbon dioxide concentrations, thus reducing carbonate availability. A prevalence of flysch-type faunas in the Paleocene has been documented for the Labrador Sea, just north of the Bonavista-Blue transect (Miller et al., 1982), and a major faunal turnover from primarily agglutinated to largely calcareous has been described for deep areas of the southern Labrador Sea (Kaminski et al.). While much of the Paleogene stratigraphic record has been lost in Blue due to the unconformity, the faunal changes in the Bonavista site during the Paleogene generally follow this pattern.

Bonavista's foraminiferal fauna goes from a primarily agglutinated assemblage with a few Nodosariids and no planktonics in the Middle Eocene (Core 3) to a mixed, much richer calcareous and agglutinated fauna with a large planktonic component at a higher stage in the Upper Eocene (Core 2). In the Late Oligocene-Early Miocene interval represented by Core 1, the fauna is again mixed, although somewhat less rich than in Core 2, and contains some taxa indicative of shallower conditions.

In a study of Paleocene flysch-type assemblages from a transect in the North Sea, Jones (1988) noted differences in agglutinated foraminiferal grain size, preservation, and composition which were apparently related to paleodepth at the various sites. He found that assemblages from upper slope locales $(200-500 \mathrm{~m})$ were fine to medium-grained, white in colour and more or less medium-sized. Middle slope $(500-1000 \mathrm{~m})$ faunas tended to be coarse-grained, coloured brownish-green to gray and relatively large in size. Basin-floor $(1000-1500 \mathrm{~m})$ agglutinants were small-sized, fine-grained and a wide range of colours.

Disregarding the colour comparisons as probably dependent on variables of sediment source, composition and related diagenetic processes, data concerning test and grain size of agglutinated specimens in the Bonavista and Blue material can be directly correlated to Jones's (1988) study. Examination of several slides prepared from Jones's study material supported this comparison.

In the Middle Eocene of the Bonavista-Blue transect area, both sites contained faunas characterized by agglutinated species of small to medium test size and fine to medium texture, as are seen in Bonavista's Core 3 and cuttings from the $4100-4680 \mathrm{~m}$ interval in Blue (Table 3). These features would tend to argue a basin floor or at least lower slope environment for the transect.

In the Late Eocene (represented by Core 2 in Bonavista and the interval $3830-4100 \mathrm{~m}$ in Blue), the agglutinated components exhibit some dramatic differences. The fauna in Bonavista remains small to medium in size but becomes coarser in grain size, approaching Jones's criteria for middle slope assemblages, but in Blue the agglutinated component becomes quite large and decidedly coarse in texture, becoming more like Jones's middle slope faunas than the upslope Bonavista assemblage, which still retains some specimens of the relatively small size of a lower slope or "basin floor" association. It is not clear why this ambiguity should exist on this transect. Gross lithological examination indicates a range of grain sizes is available for test construction at both sites, so some other parameter(s) may be of importance here. The implication here is that local conditions may complicate interbasin comparison of gross appearances of agglutinated assemblages.

In Oligocene-Miocene time (missing in Blue), Core 1 contains a typical middle slope assemblage according to Jones's (1988) standards, with numbers of large, relatively coarse-grained agglutinates. Also, the relatively few calcareous benthonic species present appear to suggest more nearshore conditions. This agrees with the seismic evidence of shallowing at the Bonavista site in late Paleogene time due to prograding deltaic sedimentation (see below).

\section{Taxonomic comparison of North Sea and Northeast Newfoundland Shelf agglutinants}

In a further comparison of Jones's (1988) data with that of the present study, the superfamilial distribution of the agglutinated 


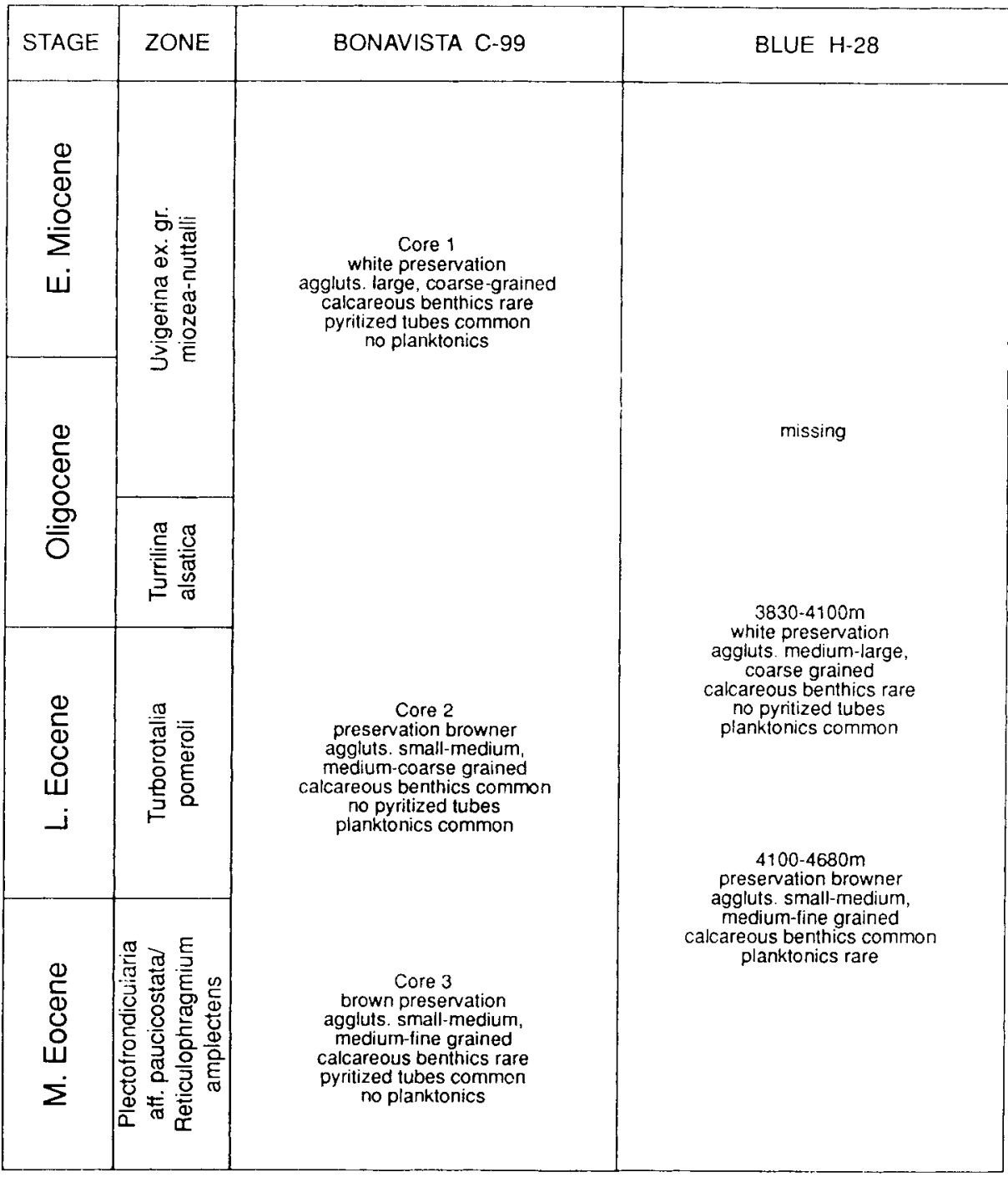

Table 3 Comparison of gross characteristics of foraminiferal assemblages in Bonavista C-99 cores and Blue H-28 cuttings.

\begin{tabular}{|c|c|c|c|c|c|c|c|c|c|c|c|}
\hline Region & \multicolumn{6}{|c|}{ North Sea (Jones, 1988) } & \multicolumn{5}{|c|}{ NE Newfoundland Shelf } \\
\hline \multirow{3}{*}{ SUPER FAMILY } & \multicolumn{2}{|c|}{$\begin{array}{l}\text { Upper } \\
\text { Slope }\end{array}$} & \multicolumn{2}{|c|}{$\begin{array}{l}\text { Middle } \\
\text { Slope }\end{array}$} & \multicolumn{2}{|c|}{$\begin{array}{l}\text { Lower } \\
\text { Slope }\end{array}$} & $\begin{array}{l}\text { Upper } \\
\text { Slope }\end{array}$ & \multicolumn{4}{|c|}{$\begin{array}{l}\text { Middle/Lower } \\
\text { Slope }\end{array}$} \\
\hline & \multirow{2}{*}{$\begin{array}{c}\text { Well } \\
1\end{array}$} & \multirow{2}{*}{$\begin{array}{c}\text { Well } \\
2\end{array}$} & \multirow{2}{*}{$\begin{array}{c}\text { Well } \\
3\end{array}$} & \multirow{2}{*}{$\begin{array}{c}\text { Well } \\
4\end{array}$} & \multirow{2}{*}{$\begin{array}{c}\text { Well } \\
5\end{array}$} & \multirow{2}{*}{$\begin{array}{c}\text { Well } \\
6\end{array}$} & \multicolumn{3}{|c|}{ Bonavista C-99 } & \multicolumn{2}{|c|}{ Blue $\mathrm{H}-28$} \\
\hline & & & & & & & Core 1 & Core 2 & Core 3 & $3830-4070$ & $4070-4100$ \\
\hline Ammodiscacea(\%) & 77 & 24 & 61 & 85 & 59 & 54 & 90 & 55 & 35 & 60 & 45 \\
\hline Lituolacea(\%) & 23 & 76 & 39 & 15 & 41 & 46 & 10 & 45 & 65 & 40 & 55 \\
\hline
\end{tabular}

Table 4 Superfamily composition of agglutinated foraminiferal species in samples from North Sea well transect (Jones, 1988) vs. present study. 


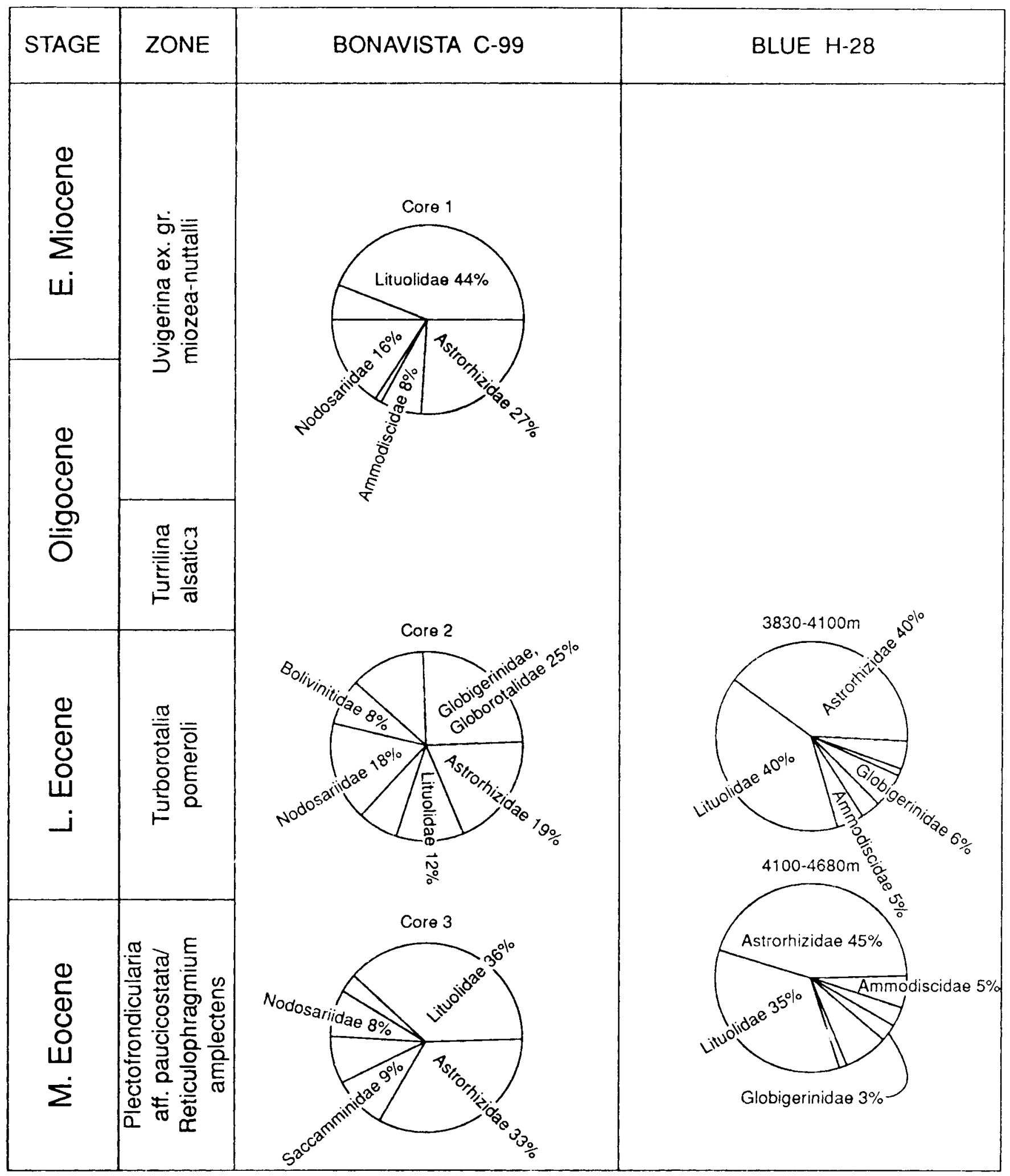

Fig 2 Pie diagrams of Bonavista C-99 and Blue H-28 assemblages showing proportions of major families. 
taxa in both data sets were examined. Table 4 presents the breakdown of numbers of specimens of each of the two principal superfamilies Ammodiscacea and Lituolacea in the six North Sea site/samples, averaged values for the agglutinated components of the samples from the three Bonavista C-99 cores, and averaged values for the same fraction of the upper and lower half of the Blue $\mathrm{H}-28$ section.

The relative abundances of the two superfamilies in samples of suggested similar depth ranges show some similarities but are not closely compatible. In Jones's two upper slope sites the relative percentages of the two groups differ widely, with Ammodiscaceans comprising $77 \%$ at most in the shallower site. In Bonavista's Core 1, also presumably an upper slope environment, Ammodiscaceans account for approximately $90 \%$ of the agglutinated component. In Jones's other sites, the percentage of Ammodiscaceans generally declines with increasing depth, with a concomitant increase in the Lituolacean fraction. The same trend is apparent in the two lower Bonavista cores, implying deeper conditions in Core 3, although the absolute numbers are somewhat different. Similarly, the upper half of the Blue section $(3830-4070 \mathrm{~m})$ shows a higher average value for percent Ammodiscaceans than does the lower half $(4070-4440 \mathrm{~m})$.

The differences in actual percentages between the North Sea and Northeast Newfoundland Shelf assemblages can easily be attributed to variances in bottom hydrological conditions as suggested by the substantially more common calcareous components in the latter region, compared to the nearly wholly agglutinated North Sea foraminifera.

If the entire foraminiferal assemblages are illustrated as pie diagrams (Fig.2), the changing nature of the assemblages through time is readily apparent.

Overall, the superfamily distributions seen in the Northeast Newfoundland Shelf assemblages tend to support a lower or middle slope environment for Bonavista Cores 2 and 3 and the Upper to Middle Eocene Blue section, and a possible upper slope regime for the Late Oligocene-Early Miocene Core 1 at the Bonavista site.

\section{Relationship to contour currents}

While direct comparisons of fossil assemblages to modern ones are not always simple, such studies often yield insights into paleoenvironments. In an examination of this problem, Scott et al. (1983), offer encouraging results, suggesting that there is good communality at the generic level, at least, between fossil Paleogene and modern slope agglutinated faunas. At the species level, however, this similarity tends to wane, in part because of differential preservation and other factors.

The primarily agglutinated assemblage seen in Core 3 may have modern analogues at the present sediment surface near the Bonavista site and on the modern lower Scotian Slope. In an ecological study of the northeast Newfoundland slope area, Schafer et al. (1983) described an association of agglutinated genera containing common Ammobaculites, Glomospira, Karreriella, Reophax, Haplophragmoides and Saccammina. Using numerical methods, they were able to correlate this assemblage with the coarser sediments, reduced temperature and slightly elevated oxygen concentrations of the Western Boundary Undercurrent (WBU) which impinges on the lower slope at a depth of approximately $2500 \mathrm{~m}$ or more. In a study of modern benthic foraminiferal faunas on the lower Scotian Slope, Schroder (1986) found several agglutinated species which seemed to favour areas overlain by the WBU. Table 5 provides a comparison of the common agglutinated taxa from the three sample suites. While the content of these modern agglutinated assemblages are not identical to that seen in Core 3 , there appears to be enough similarity to suggest some communality in bottom hydrologic conditions.

Although the WBU is a relatively recent phenomenon (Schnitker, 1979), contour currents in general are not, and many workers suggest major increases in bottom water circulation, with concomitant initiations of deep boundary currents in the Late Eocene to early Oligocene (Miller et al., 1984). The presence of seismic reflector R4 at DSDP Site $112\left(5401^{\prime} \mathrm{N}, 4636^{\prime} \mathrm{W}\right.$; southern Labrador Sea) may indicate the presence of an unconformity which could be the result of contour-current erosion at about this time just north of the Bonavista-Blue transect (Miller et al., 1982). Also, the Late Eocene-Middle Miocene unconformity (discussed further below) in Blue may partly be a result of this increased circulation. Furthermore, since there appears to be no corresponding hiatus in upslope Bonavista, the inference is that the upper limit of this late Paleogene western boundary undercurrent lay between the coeval paleodepths of these two sites.

Core 1 is also nearly devoid of planktonic foraminifera, and contains abundant pyritized tubes. Several of its few calcareous species, however, indicate slightly shallower conditions, and the agglutinated forms include a relatively higher percentage of Lituolids, again implying reduced water depth. Seismic line 84-3 Lithoprobe East, passing through the Bonavista site reveals the progressive thickening of the sedimentary wedge during the Late

Genus Schroder, 1986 IV Schafer et al., 1983 "C

Bonavista C -99 Core 3

\begin{tabular}{|c|c|c|c|c|c|c|}
\hline Ammobaculites & $11 \%$ & & PP4 & yes & $H$ & yes \\
\hline Bathysiphon & $11 \%$ & & PP4 & & H & yes \\
\hline Budashevella & $\pi \%$ & & PP4 & & H & yes \\
\hline Cydammina & $\mathbb{H} \%$ & & PP4 & & H & yes \\
\hline Glomospira & $11 \%$ & & PP4 & yes & H & yes \\
\hline Haplophragmoides & $11 \%$ & & PP4 & yes & H & yes \\
\hline Hormosina & $H \%$ & & PP4 & & H & yes \\
\hline Hyperammino & $\pi \%$ & yes & PP4 & & H & yes \\
\hline Korreriella & $11 \%$ & & PP4 & yes & H & yes \\
\hline Recurvoides & $1+\%$ & & PP4 & yes & $H$ & yes \\
\hline Reophax & $1 t \%$ & & PP4 & yes & & \\
\hline Rhobdammino & $11 \%$ & yes & & & & \\
\hline Rhizommino & $11 \%$ & & PP4 & yes & H & yes \\
\hline Saccammina & $\mathrm{tt} \%$ & & PP4 & yes & H & yes \\
\hline Spiroplectammino & $11 \%$ & & PP4 & yes & & \\
\hline Textulario & $H \%$ & & PP4 & & H & yes \\
\hline Trochamminoides & $H \%$ & & PP4 & & $H$ & yes \\
\hline
\end{tabular}

Note: Schroder's samples also listed Cribrostomoides, and those from Schafer et al. also contained Sigmoilopsis, but those taxa only appeared in the Holocene and Miocene respectively (Loeblich and Tappan, 1988).

Table 5. Common agglutinated genera in modern Western Boundary Undercurrent environments on the Scotian Slope (Schroder, 1986), East Newfoundland Slope (Schafer et al., 1983) and Bonavista C-99 Core 3 


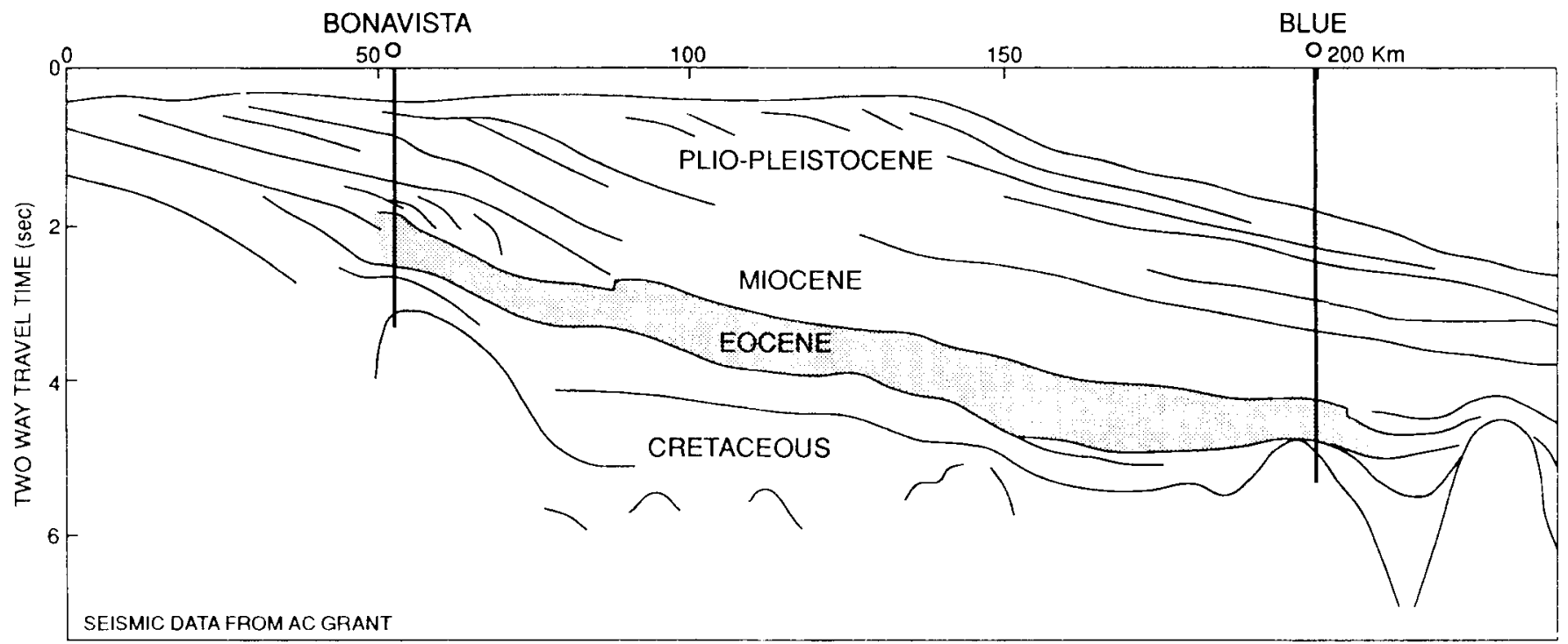

Fig 3 Scismic section of line 84-3 Lithoprobe East, 1984, AGC.

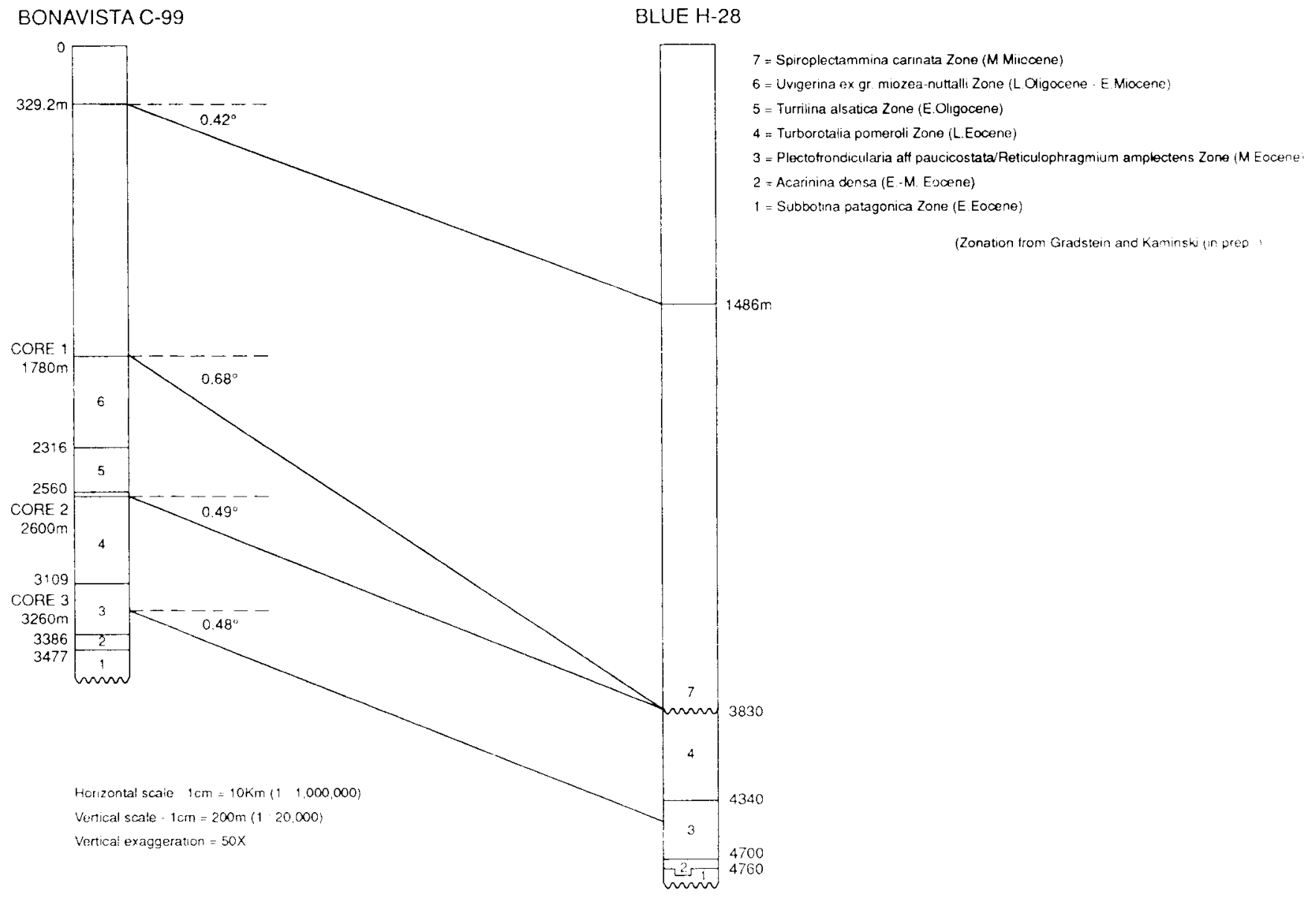

Fig 4 Paleoslopes of Bonavista - Blue transect. 
Oligocene to Early Miocene time represented by Core 1, thereby reducing the water depth (Fig.3 and A.C. Grant "(ACG)", pers. comm., 1989).

The Late Eocene interval $3830-4340 \mathrm{~m}$ in the Blue well is fairly uniform in foraminiferal composition, although the upper $300 \mathrm{~m}$ or so are slightly richer in planktonics averaging about $6 \%$, whereas below $4100 \mathrm{~m}$ the planktonic component drops to approximately $3 \%$.

In general, the foraminiferal assemblage seen in Blue $\mathrm{H}-28$ from $3830 \mathrm{~m}$ down to $4070 \mathrm{~m}$ closely resembles that of Bonavista's Core 1 in details of preservation. In both sites, agglutinated forms exhibit a white, sugary appearance and species common to both show very similar size ranges. Pressing the comparison, Bonavista's Core 1 assemblage closely matches that seen in this interval of Blue H-28, minus Blue's planktonics and most of its calcareous benthonics. One noticeable difference, however, is the nearly total absence in Blue of the pyritized tubes so common in Bonavista's Core 1, implying that whatever organism made the tubes at the Bonavista site was not present at the deeper Blue location.

\section{Paleoslope reconstruction}

Paleoslope reconstruction of the Bonavista Blue transect (Fig.4) shows a marked increase in slope from approximately $0.45^{\circ}$ and $0.41^{\circ}$ in the times represented by Cores 3 and 2 respectively to $0.64^{\circ}$ at the time of deposition of the Core 1 sediments in the Late Oligocene-Early Miocene, based on the depth of the Miocene/Eocene hiatus in Blue.

This hiatus has effectively wiped out the foraminiferal record of paleoenvironments at the Blue site for this Late Eocene to Middle Miocene period (Fig.5), making direct comparison to the Bonavista site impossible. However, some hints remain of the differing depositional realms at the two localities. When the stratigraphic tops of the species common to both wells are
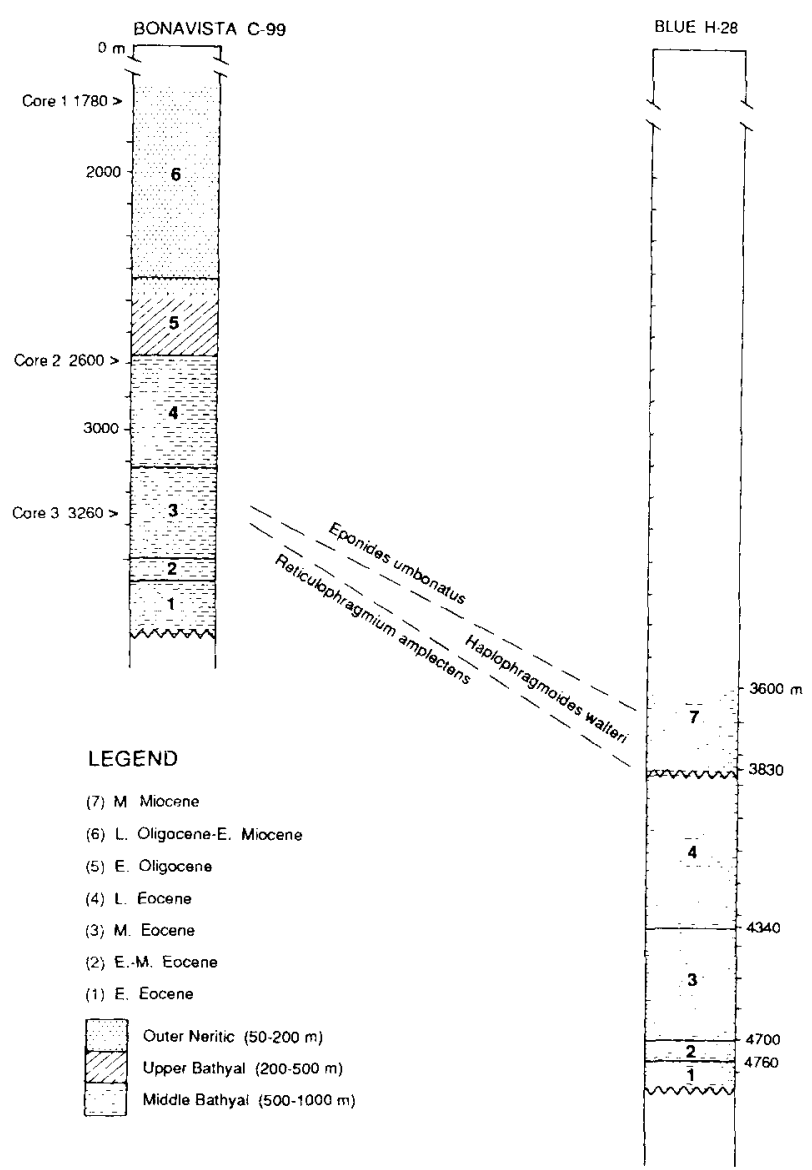

Fig 5 Correlation chart showing ages and environments of Bonavista and Blue

\section{BONAVISTA C-99}

\section{BLUE H-28}
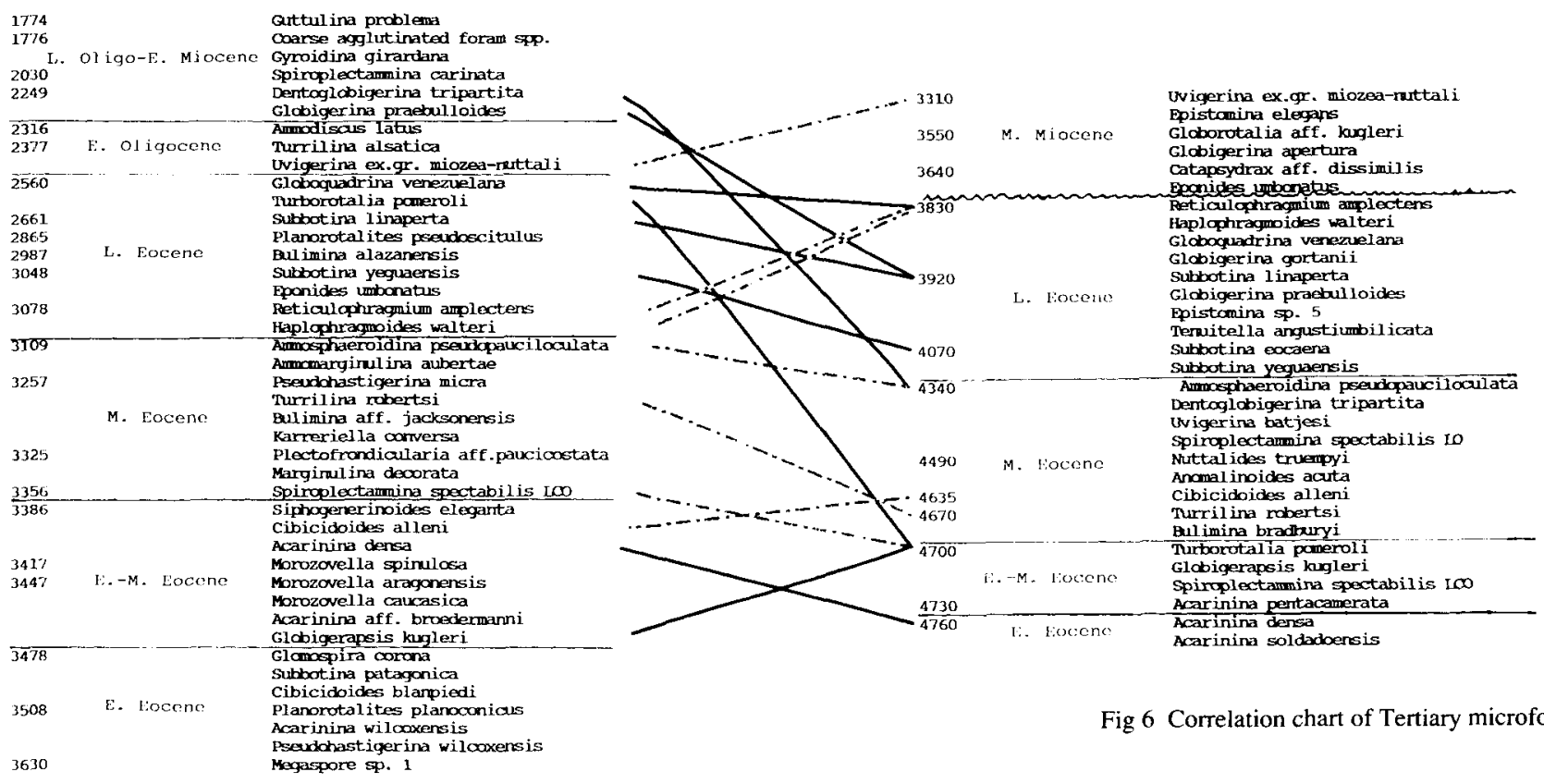

Fig 6 Correlation chart of Tertiary microfossil tops. 
correlated (Fig.6), the results show the generally orderly stratigraphic succession of species well-documented from this region (Gradstein \& Agterberg, 1982), punctuated by a few interesting anomalies.

Most obviously, the tops of certain planktonic species appear to be somewhat higher in Bonavista. Dentoglobigerina tripartita and Globigerina praebulloides, for instance disappear in the Early Oligocene in Bonavista, yet apparently disappear well below the truncated top of the Upper Eocene section in Blue. This anomaly can probably be attributed to the hiatus in the Blue well. More dramatically, Turborotalia pomeroli occurs up to the top of the Late Eocene in Bonavista, but tops out at Middle Eocene levels in Blue, most probably a victim of inconsistencies inherent in sampling of rare discrete events.

Certain benthonic species also exhibit unusual occurrence patterns in the two wells. Reticulophragmium amplectens and Haplophragmoides walteri disappear in lower levels of the Upper Eocene in Bonavista, but persist to the top of the truncated Upper Eocene in Blue, evidence that an unknown but possibly quite thick section of the Upper Eocene is missing at the Blue site.

This idea is supported by the relative tops of some other benthonic taxa such as Ammosphaeroidina pauciloculata, Spiroplectammina spectabilis and Cibicidoides alleni, which have extinction levels at similar Middle Eocene ages in both wells, an indication that up to at least the Late Eocene, bottom environments at both sites remained somewhat similar.

Two calcareous benthonic species, Eponides umbonatus (topping in mid-Late Eocene in Bonavista) and Uvigerina ex gr. miozea-nuttalli (Early Oligocene in Bonavista) persist to the Middle Miocene at the Blue site. Although little environmental information is available on the recently-designated $U$. ex. gr. miozea-nuttalli (Thomas, 1988), Eponides umbonatus (= Oridorsalis umbonatus) is a well-known modern cosmopolitan inhabitant of cool, lower slope conditions and now occurs frequently at depths of $2750 \mathrm{~m}$ and lower on the Scotian Slope (Thomas, 1987), and everywhere below $500 \mathrm{~m}$ on the northeast Newfoundland margin (Cole, 1981). The E. umbonatus data, then, further supports a progressive shallowing of the Bonavista site in post-Late Eocene time, contrasting with the continued bathyal depth of the Blue location during that period.

\section{INFERRED SEDIMENTATION AND HYDROLOGIC HISTORY OF THE BONAVISTA-BLUE TRANSECT}

Synthesizing various aspects of the foraminiferal assemblages found in the two wells enables reconstruction of Late Eocene to Oligocene paleoenvironments of the sites:

1. In the Middle Eocene, both sites appear to have been subject to the kinds of conditions (rapid, organic-rich clastic sedimentation, poor circulation) which would support a flourishing "flysch-type" primarily agglutinated foraminiferal fauna and simultaneously suppress developement of a rich calcareous association. The planktonic foraminifera present at the Blue site in this interval are in keeping with its more seaward position on the transect. The nature of the benthic assemblages at both sites suggest a depth range of at least $1000 \mathrm{~m}$. For unknown reasons, however, the burrowing organism responsible for the pyritized tubes so common at the Bonavista site either did not colonize the more offshore Blue locality, or its tubes were not preserved there.

2. By Late Eocene time both sites appear to have shallowed somewhat, with the foraminiferal assemblages at both localities taking on some of the characteristics of middle slope $(500-100-\mathrm{m})$ faunas. At Bonavista, however, a large and diverse calcareous component is present, with most specimens generally representing common mid-slope taxa. The "pyritized tube" organism has either disappeared from the site, or, more likely, diagenetic conditions unfavorable for the formation of pyrite prevail there. At Blue, the agglutinants have become classic "mid-slope" in appearance, but calcareous benthic species are still uncommon, even though the preservation of planktonic forms appears reasonably good. Perhaps the quality of planktonic preservation is a function of the rapid sedimentation rate at the site, as evidenced by the comparatively thick, albeit truncated Late Eocene section. Relative proportions of agglutinated taxa belonging to the superfamilies Ammodiscacea and Lituolacea tend to support this hypothesis.

3. By Late Oligocene-Early Miocene time deltaic progradation of sediments has shoaled the Bonavista site somewhat, allowing the colonization of some shallower-dwelling calcareous forms, and initiating a normal mid-slope agglutinated fauna. For some reason the "pyrite tube" organism (or conditions right for the pyritization of its burrows) re-inhabits the site. Coeval events at the Blue site are unknown.

4. According to previous researchers, some time around the beginning of the Oligocene saw the initiation of more vigorous deep circulation in northern Atlantic areas, which in turn extirpated flysch-type agglutinated assemblages in much of the region. This increased circulation also triggered the developement of contour currents, which, in turn, presumably created the late Paleogene erosional events seen in so many deep locations such as in the Blue well. Whether or not any of these events affected the Bonavista site is unclear; there do not, at least, appear to be any long gaps in the Oligocene record at Bonavista.

5 . The apparent continuity of the stratigraphic record at the Bonavista site indicates that its mid-slope $(500-1000 \mathrm{~m})$ bathymetric position lay upslope of the upper limit of the Paleogene western boundary undercurrent, an important clue to reconstructing Paleogene circulation history and paleoenvironments on the northeast Newfoundland margin.

\section{ACKNOWLEDGEMENTS}

Thanks to F.M. Gradstein (AGC) and G.D. Jones (Unocal) for their many comments and suggestions which greatly improved the manuscript. Figures were drafted by G.M. Grant and word processing was by N. Koziel (both of AGC). A.C. Grant (AGC) kindly provided seismic information and insights.

\section{Manuscript received August 1990 \\ Revised manuscript accepted February 1991}

\section{REFERENCES}

BP Exploration Canada, 1975. Well history - suspension report. BP Columbia Bonavista C-99. BP Exploration Canada. Calgary.

Cole, F.E. 1981. Taxonomic notes on the bathval zone benthonic foraminiferal species off Northeast Newfolmdland. Bedford Institute of Oceanography Report Series, No. BI-R-81-7, June, 1981, 121 p., Dartmouth, Nova Scotia.

Gradstein, F.M., 1975. Biostratigraphy (Foraminifera) and depositional environment of BP Columbia Bonarista C-99. East Newfotmdland Basin. Report No. EPGS-PAL.33-75FMG, 7p. (Unpublished manuscript)

Gradstein, F.M. and Agterberg, F.P., 1982. Models of Cenozoic foraminiferal stratigraphy - Northwest Atlantic Margin. In Cubitt, J.M. and Reyment, R.A. 
(Eds.), Quantitative Stratigraphic Correlation. John Wiley and Sons, Chichester, U.K., 119-174.

Gradstein, F.M. and Berggren, W.A., 1981. Flysch-type agglutinated foraminifera and the Maestrichtian to Paleogene history of the Labrador and North Seas. Mar. Micropal.. 6, 211-268.

Gradstein, F.M. and Kaminski, M.A., in prep. Cenozoic biostratigraphy and paleoceanography, North Sea and Labrador Shelf.

Gradstein, F.M. and Srivastava, S.P., 1980. Aspects of Cenozoic stratigraphy and paleogeography of the Labrador Sea and Baffin Bay. Palaeogeog., Palaeoclim., Palaeoecol., 30, 261-295.

Gradstein, F.M. and Thomas, F.C., 1983. Stratigraphy and depositional environment of Texaco Blue H-28. Report No. EPGS-PAL.1-83FMG/FCT, 3p. (Unpublished manuscript)

Grunig, A. and Herb, R., 1980. Paleoecology of Late Eocene benthonic foraminifera from Possagno (Treviso - Northern Italy). In: Ingle, J.C. Jr., Kennett, J.P., Kolpack, R. and Vincent, E. (Eds.), Studies in Marine Micropaleontology and Paleoecology. Cushman Foundation, Special Publication No.19, 68-85.

Grzybowski, J., 1898. Mikroskopowe badznia namntow wierthiczych 2 kopala naftowych. I. Pas potocki i okolice Krosna. II. Uwagi ogolne. Kosmos, 22, 393439.

Jones, G.D., 1988. A paleoecological model of Late Paleocene "flysch-type" agglutinated foraminifera using the paleoslope transect approach, Viking Graben, North Sea. Abhandlungen der Geologische Bundesanstalt, Vienna, Band 41, 143153.

Kaminski, M.A., Gradstein, F.M. and Berggren, W.A., 1989. Paleogene benthic foraminifer biostratigraphy and paleoecology at Site 647, southern Labrador Sea. In Srivastava, S.P., Arthur, M. et al. (Eds.), Proceedings of the Ocean Drilling Project, Results, v.105. Ocean Drilling Project, College Station, Texas, 705-730.

Loeblich Jr., A.R. and Tappan, H., 1988. Foraminiferal genera and their classification. Van Nostrand Reinhold Co., New York, 2 vol., 970 p. +217 p.

McNeil, D.H., 1983. Paleogene agglutinated foraminifera from the Mackenzie Delta and Beaufort Sea areas of Arctic Canada. In: Verdenius, J.G., van Hinte, J.E. and Fortuin, A.R. (Eds.), Proceedings of the First Workshop on Arenaceous Foraminifera, 7-9 September, 1981. Publication No.108, Institutt for Kontinentalsokkelundersokelser, Trondheim, Norway, 109.

Miller, K.G., Curry, W.B. and Ostermann, D.R., 1984. Late Paleogene (Eocene to Oligocene) benthic foraminiferal oceanography of the Goban Spur region, Deep Sea Drilling Project Leg 80. In: Graciansky, P.C., Poag, C.W. et al. (Eds.), Initial Reports of the Deep Sea Drilling Project, LXXX, Washington, (U.S. Government Printing Office), 505-538.

Miller, K.G., Gradstein, F.M. and Berggren, W.A., 1982. Late Cretaceous to Early Tertiary agglutinated benthic foraminifera in the Labrador Sea. Micropaleomt., New York, 28, 1-30.

Schafer, C., Cole, F. and Carter, L., 1983. Paraecology of bathyal zone foraminifera genera and species assemblages off Northeast Newfoundland. In: Verdenius, J.G., van Hinte, J.E. and Fortuin, A.R. (Eds.), Proceedings of the First Workshop on Arenaceous Foraminifera, 7-9 September, 1981. Publication No. 108, Institutt for Kontinentalsokkelundersokelser, Trondheim, Norway, 133-146.

Schnitker, D., 1979. The deep waters of the western North Atlantic during the past 24,000 years, and the re-initiation of the Western Boundary Undercurent. Mar. Micropaleont., 4, 265-280.

Schroder, C.J., 1986. Deep-water arenaceous foraminifera in the Northwest Atlantic: Ocean. Canadian Technical Report of Hydrography and Ocean Sciences, Dartmouth, Nova Scotia, No.71, $191 \mathrm{p}$.

Scott, D., Gradstein, F.M., Schafer, C., Miller, A. and Williamson, M., 1983. The Recent as a key to the past: does it apply to agglutinated foraminiferal assemblages? In: Verdenius, J.G., van Hinte, J.E. and Fortuin, A.R. (Eds.), Proceedings of the First Workshop on Arenaceous Foraminifera, 7-9 September, 1981. Publication No. 108, Institutt for Kontinentalsokkelundersokelser, Trondheim, Norway, 147-158.

Texaco Canada Resources Ltd., 1980. Well Report - Texaco Shell et al. Blue H-28. Texaco Canada Resources, Ltd., Calgary, Alberta, 32p. (Unpublished manuscript)

Thomas, F.C., 1987. Lower Scotian Slope benthic foraminifera-their taxonomy and occurrences. Canadian Technical Report of Hydrography and Ocean Sciences, Dartmouth, Nova Scotia, no.81, 68p.

Thomas, F.C.. 1988. Taxonomy and stratigraphy of selected Cenozoic benthic foraminifera, Canadian Atlantic Margin. Micropaleont., New York, 34, 67-82.

Thomas, F.C. and Murney, M.G., 1985. Techniques for extraction of foraminifers and ostracodes from sediment samples. Canadian Technical Report of Hydrography and Ocean Sciences, Dartmouth, Nova Scotia, no.54, 24p.

Toxwenius, B.W., 1983. Paleogene arenaceous foraminiferal assemblages from the West Greenland Basin and their paleoecological implication. In: Verdenius, J.G., van Hinte, J.E. and Fortuin, A.R. (Eds.), Proceedings of the First Workshop on
Arenaceous Foraminifera, 7.9 September, 1981. Publication No. 108, Institutt for Kontinentalsokkelundersokelser, Trondheim, Norway, 171. 